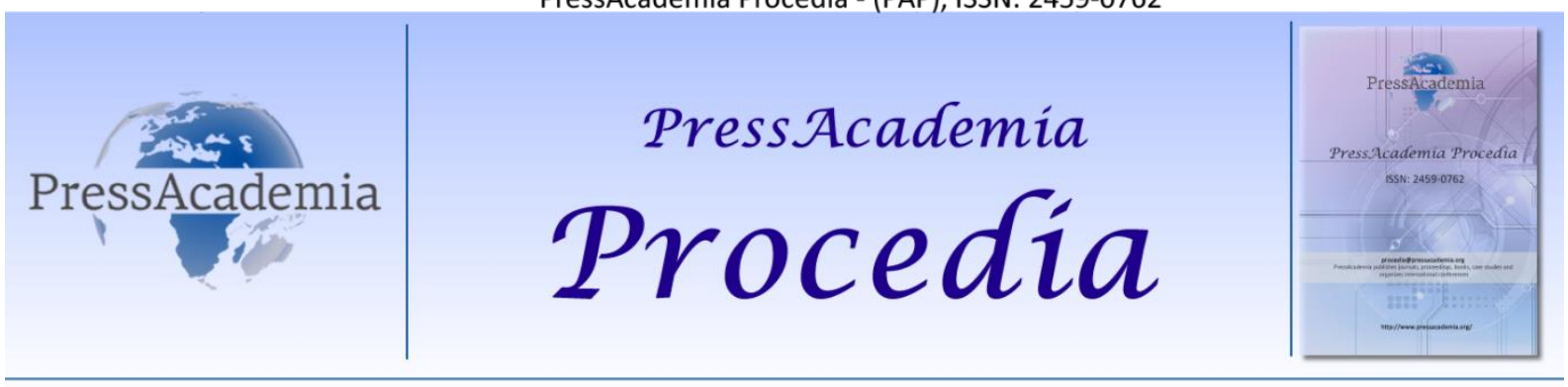

2nd World Conference on Technology, Innovation and Entrepreneurship

May 12-14, 2017, Istanbul, Turkey. Edited by Sefer Şener

\title{
REFORMING TURKEY'S HIGHER EDUCATION SYSTEM IN ORDER TO ATTAIN HIGH INCOME, INNOVATION DRIVEN, INTELLECTUAL ECONOMY' STATUS
}

\author{
DOI: $10.17261 /$ Pressacademia.2017.518 \\ PAP-WCTIE-V.4-2017(10)-p.62-69
}

\section{Halil Kursad Aslan}

İstanbul Medipol University Dept of Pol Sci and Intl Relations hkaslan@medipol.edu.tr

\begin{abstract}
Middle-income trap is a status of slowing down and stagnation in economic growth when countries reach middle-income levels. Countries have to restructure their economies fundamentally in order to get rid of this trap; and they restructure national resources, particularly human capital for higher education, technological production and innovation systems. Under realities of the global economic system innovation capacities of nations along with knowledge production have gained extra importance. Fresh perspectives share the view that competitiveness of national economies is founded on innovation; and formulating a national innovation policy especially in developing countries seems to be essential for economic growth and development. In this light a crucial role governments are expected to assume is reforming research institutions, technology transfer institutions and higher education systems in general. In this paper, I will analyze these perspectives with a specific focus on Turkey's national innovation efforts and higher education system.
\end{abstract}

Keywords: Middle-income trap, higher education, total factor productivity, innovation, development JEL Codes: D83, N75, O38, 123

\section{INTRODUCTION}

This paper analyzes the concept of knowledge economy with a special focus on Turkey in light of developments in the global political economy. While analyzing the knowledge economy this study borrows from the newly emerging middle-income trap literature. Having defined the main character of the international political economic system as the "knowledge economy" it would be easy to expect that nations compete with each other to amass intellectual property, knowledge and know-how as much as possible. In the international relations discipline realist argument highlights that since all politics among nations are a zero-sum game, states brutally compete with each other to ensure their own benefits outweigh that of others. In the global economy of the $21^{\text {st }}$ century the most important tool is knowledge, which means intellect plus technology. Therefore, the primary goal of all state leaders would be to gain advantage in terms of the knowledge economy against all other competitors. The balance and distribution of power among states in the global political system could change if one state constantly accumulates more knowledge than others. Thus, the possession of knowledge is an important indicator in the global political system.

Another major concept that this paper employs is the middle income trap. This study analyzes the concept of middle-income trap in the context of international relations and the global political economy by focusing on the Republic of Turkey. In light of macro economic performance of Turkey in the past decade, this study tries to find out whether there are indications of the middle-income trap or not. Additionally, technology and human capital investments along with education policies are emphasized as the most important reform area to get rid of the middle-income trap and move to the high income levels. It is important to note that particular concentration is on the reform needs of Turkey's higher education system.

A middle-income trap is essentially characterized by a slowdown in the pace of economic growth as well as productivity. Countries that grew to middle-income levels subsequently stagnate and fail to grow to high income, advanced-country levels (Kharas \& Kohli, 2011). In other words, the "middle-income trap" is a phenomenon of hitherto rapidly growing economies stagnating at middle-income levels for extended periods of time (Aiyar et al, 2013). In other words, overwhelming majority of mid-income countries have remained in the same range of income for extended time periods. Probably most of them will remain as such for many years to come (Gill \& Kharas, 2008; Wilson, 2014). The World Bank estimates that of 101 middleincome economies in 1960, only 13 have become able to achieve high income status by 2008 (Agenor et al, 2012 ).

There is no commonly agreed definition of the term, middle-income trap, in the literature; however, the phenomenon is generally described in terms of relative "catch-up" with the United States' per capita income levels or in terms of the 
number of years a country takes to move from one income level to one step upper level based on threshold numbers (Felipe et al, 2012).

A close examination of all macroeconomic data would show that advanced countries have consistent developmental trajectories. Accordingly, in this paper Turkish economy and its structural problems are analyzed with an eye towards the concept of middle income trap. Looking at economic conditions and the position it occupies in the global context in terms of the knowledge economy one might ask whether Turkey would remain stuck in the middle income trap. By employing several parameters and indicators such as competitiveness, productivity, innovation capacity etc. this paper tries to have a better understanding of Turkey's propensities to fall into the mid-income trap or alternatively attain high income levels with innovation-driven knowledge economy.

A particular attention is paid to the Turkish higher education system as a potential policy area with which Turkey might achieve to reach high income category. Thus, experiences of country cases are essential for Turkey in order to design a suitable development program in which higher education and innovation systems are crucial. In the following section a theoretical and conceptual sketch about the middle-income trap is given. There is also a historical tour about the South Korean development model and particularly investments in the higher education system. In the following sections major developments in the global economy and political system are highlighted; moreover, some negative side effects of development trajectories in light of the global future are also mentioned here. Major points regarding the Turkish economy and higher education system are touched upon and some concluding remarks are also presented.

\section{LITERATURE REVIEW}

\subsection{Middle-Income Trap Literature}

After World War II an extensive literature has emerged about economic growth and development. The most notable model was designed by Robert Solow whose model was extremely simplified. The Solow model, which attempted to explain the determinants of long-run economic growth by means of capital accumulation and labor growth, has become very popular in this body of literature. Solow model has built on four variables: output, capital, labor and the effectiveness of labor. The main assumption of the model was that there are constant returns to scale with regard to capital and effective labor. In the following decades new studies have been introduced. The goal of these new studies was to explain productivity increases that were not revealed by the Solow model. Later scholars turned their attention so as to explain the causes and variations in long-term growth. Thus, new economic growth studies concentrated on expenditures for research and development activities.

Scholars compared country cases in terms of their growth differentials. For example, Robert Lucas (1993) asked why South Korea has achieved a tremendous numbers in its growth of national income while the Philippines could not attain such a success. However, in 1960 both countries had about the same standard of living, as measured by their per capita GDPs of about $\$ 600$, population numbers, urbanization levels etc. From 1960 to 1988, in the Philippines average annual per capita GDP growth was about 1.8 percent; in S. Korea, over the same period, this number was 6.2 percent.

So the critical question is why did Korea, Singapour and Taiwan achieved sustainable development records and higher living standard, and not in the Philippines, Mexico and Brazil? In other words, the obvious question "given the fact that while some countries have made a difference and jumped into the camp of the advanced industrialized countries with high per capita income, why have other countries remained as middle income countries for an extended period of time?" still needs a coherent answer with a basic theoretical sketch.

In the economic growth studies, "middle-income trap" is a relatively new phenomenon that stands for countries where rapidly growing economies stagnates at some points in their economic growth history. More specifically, middle-income trap is growth slowdowns that are identified as large sudden and sustained deviations from the growth path predicted by a basic conditional convergence framework (Aiyar 2013).

As of 2016, low-income economies are defined as those with a GNI per capita of $\$ 1,025$ or less; lower middle-income economies are those with a GNI per capita between $\$ 1,026$ and $\$ 4,035$; upper middle-income economies are those with a GNI per capita between $\$ 4,036$ and $\$ 12,475$; high-income economies are those with a GNI per capita of $\$ 12,476$ or more. As of 2016 Turkey sits in the upper middle-income group with its approximately $\$ 9500$ per capita income.

As of 2016 among its 188 members, the World Bank classifies a country as an upper middle income country if its per capita income is in the 4,036-12,476 dollars range. The issue faced by many middle-income countries is whether or not they are able to advance towards the high-income group. It should be noted that the World Bank classifies countries based on estimates of gross national income (GNI) per capita for the previous year. The World Bank data indicates that as of the year 2015 middle income countries make almost two third of the global population (5 out of 7,5 billion) and gets almost one third of global income (Gill \& Kharas, 2015).

There are many common issues faced by middle-income countries, they all struggle to advance towards the high-income levels. Characteristically, these countries have remained stuck in middle income growth trap because they are unable to either attract sufficient funds from domestic and/or outside sources, political instabilities, poor educational and health 
standards, low levels of human capital, inadequate physical and institutional infrastructures, lack of diversification in manufacturing and exports and the most importantly total factor productivity.

In Table 1 below human development indicators could be seen for some selected countries. All these countries in the Table (except Turkey) achieved to get rid of middle income trap in the past decades. Figures for Turkey can be seen in the last row for comparasion purposes. It is clear that socio-economic indicators of those countries are significantly better than Turkey. Common characteristics of these achievers could help trapped countries. Six countries in the list remained in the "very high human development" group. Economic and social indicators are balanced. All of them have splendid education and life expectancy figures; average schooling is generally above 10 years for their population.

Table 1: Human Development Indicators for Some Selected Countries (2016)

\begin{tabular}{|l|l|l|l|l|l|}
\hline Countries & $\begin{array}{l}\text { Population } \\
\text { (in million) }\end{array}$ & HDI rank & $\begin{array}{l}\text { Per Capita } \\
\text { Income \$ (PPP) }\end{array}$ & $\begin{array}{l}\text { Life } \\
\text { Expectancy }\end{array}$ & $\begin{array}{l}\text { Average } \\
\text { Schooling }\end{array}$ \\
\hline Singapore & 5,5 & 5 & 85,382 & 82,6 & 10,2 \\
\hline Ireland & 4,6 & 8 & 68,513 & 81,1 & 11,7 \\
\hline Hong Kong & 7,3 & 12 & 56,923 & 83,9 & 10,1 \\
\hline Japan & 126,9 & 17 & 40,763 & 83,6 & 11,6 \\
\hline S. Korea & 50,6 & 18 & 34,647 & 82,1 & 11,9 \\
\hline Spain & 46,4 & 27 & 34,906 & 83,0 & 9,8 \\
\hline Turkey & 78,6 & 71 & 20,008 & 75,3 & 7,9 \\
\hline
\end{tabular}

Source: "Human Development Report-2016;" For Population Numbers "World Development Indicators-2016"

The middle-income-growth trap is related to the transformative difficulties of the national economies. As a country becomes richer the structure of the national economy evolves from economic activities with low productivity into relatively high-productivity ones. At the early stages of development history labor migration from rural areas to urban centers are observed. This creates abundant pool of cheap labor and comparative advantage for low technology manufacturing sectors.

At the early stages of their developmental efforts these countries experience an input-driven production where the achievement of a moment of growth is not difficult since labor is cheap and abundant. These countries provide large productivity gains at first through a reallocation of rural labor from the agricultural sector to the relatively high-productivity light industrial manufacturing activities. After a certain time has elapsed, these new urban classes reach middle-income levels, the pool of low wage workers diminishes and wage levels gradually rise. Wages increase as this economy evolves from low-skilled labor intensive activities into relatively advanced and sophisticated ones. As discussed in the literature the progression from middle to high income is not an easy and guaranteed destination in a linear growth path (Felipe et al., 2012; Berg et al., 2012). The types of goods and services produced and exported would not have the same impact for further growth and development in this economy. At some point it becomes harder to increase the per capita income. Hence, the original cost advantage erodes and as time passes relative competitiveness decreases.

In the development literature it is well documented that hardships for countries in their mid-income stages are essentially due to productivity issues. According to a World Bank research $85 \%$ of the slowdown in the rate of output growth in midincome economies is explained by total factor productivity growth (Agenor et al, 2012). In other words, the growth of the economy should be coupled with improvements in the total factor productivity. In order to be able to compete successfully in the global market a mid-income country must be equipped with high quality human capital, labor pool and technological advancements. In these countries factors and advantages that contribute to extraordinary growth records during early periods of developmental efforts would fade when middle- and upper-middle-income levels are reached. Hence national governments are supposed to conduct additional reforms in the political and economic spheres. It is clear that governments are required to extend reforms so as to improve infrastructure, health and education to supply a well educated, healthy and trained labor force for the transition to higher income levels.

A middle-income trap is essentially characterized by a slowdown in the pace of economic growth as well as productivity. So what is required for a country to avoid the middle-income trap? In order to answer this question for the Turkish economy we could look at the experiences of countries that recently achieved high income status such as South Korea, Spain, Ireland, Portugal, and Singapore. These countries had managed to overcome the middle-income trap and in recent decades managed to reach the high-income level. A simple answer is that these countries had concentrated on their total factor productivity which accounted for the national economy's transformative dynamism in regards to its comparative advantage in labor, capital and technology. Gains in efficiency may come from all economic factors or inputs into the production processes. Thus, improvements in labor (human capital and education), technological advancements (innovation) and 
efficiency gains in capital (saving and investment) are all important so as to catch the total factor productivity. For instance, in order to avoid the trap, South Korea strengthened its education system in order to provide for the essential standard required of its human resources. It also prioritized research and development and improved its institutional system leading to a dynamic private sector.

\section{DATA AND METHODOLOGY}

This study aims to combine middle-income literature with comparative higher education policies with an eye towards evolution of the global political economy structures. Methodologically, comparative policies and country cases are employed with qualitative approach. Despite numerous theories, models, and researches in the social science fields interdisciplinary studies are relatively shallow, and they still faces enormous challenges. At the center of the paper the Turkish higher education system resides. In this context, several parameters are collected from official sites regarding enrolment rates, faculty and student compositions, publication records, university rankings, public expenditures, research and development activities, and they are analyzed so as to provide policy recommendations. Comparisons with successful developers and other countries, OECD members and their macroeconomic and developmental figures are provided to depict the relative position of Turkey. Several official and private data sources are used from national institutions such as Turkish Statistical Institute (TÜiK), Turkish Higher Education Council (YOK), and The Scientific and Technological Research Council of Turkey (TÜBITAK). Additionally, data also obtained from major international organizations such as OECD, UNDP, and Worldbank.

\section{FINDINGS AND DISCUSSIONS}

It is useful to analyze the main characteristics of the middle income nations such as Brazil, South Africa, Thailand, Malaysia and Mexico. By comparing these cases it is possible to derive some lessons and identify the difficulties they face in the social, political and economic areas. Brazil, Mexico and South Africa are among the most prominent examples of countries that have been associated with the middle-income trap. What should not be done can be learned from these countries. It is also useful to analyze successful cases in the recent decades: Japan, South Korea, Hong Kong, Taiwan and Singapore.

In the last decades there are very limited countries that achieved high income status. South Korea is the most appropriate case for Turkey. South Korea, which had similar developmental level with Turkey at the beginning of the 1980s, made a great transformation throughout the 1990s and following years.

In the 1990s, which are the lost years of Turkey's development record, South Korea has completed the infrastructure necessary for information society and innovation. According to 2015 figures, South Korea's economy has a size of 1.2 trillion dollars while Turkey has 800 billion dollars; South Korea exported goods and services of about 550 billion dollars, 120 billion dollar trade surplus, and it is the world's sixth largest exporter; Turkey exported goods and services of 152 billion dollars value, 48 billion dollars trade deficit, and it is the 30th exporter in the world rank. More importantly, $27 \%$ of South Korea's exports are advanced technology products while it is $2 \%$ for Turkey. The share of advanced technology products in exports is around 10\% for Indonesia, Greece and Brazil, 15\% for Germany and Japan, and 25\% for countries such as South Korea, USA and China.

Table 2: Proportion of Advanced Technology Products in Manufacturing Industry Exports (2015)

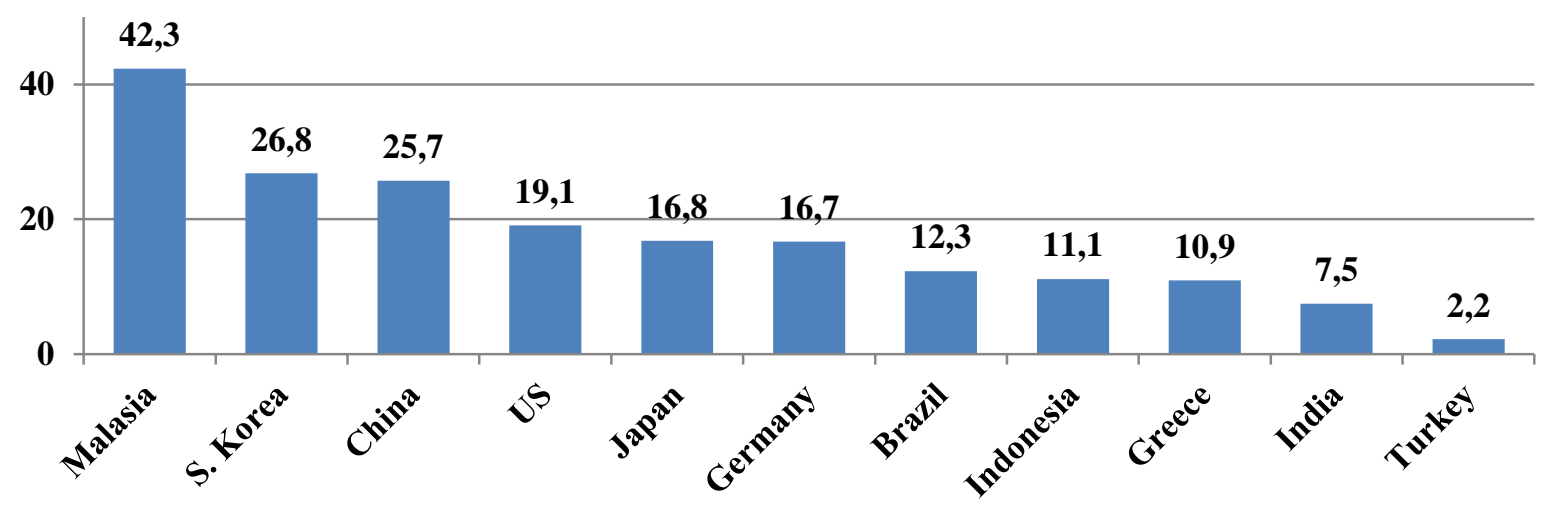

Source: World Bank, "World Development Indicators-2015"

It is obvious that there are some preconditions to gain competitive advantage in the world markets. Six key points are highlighted in the process of transforming national economies in successful countries (Kharas and Kohli, 2011). First, while the primary criterion for achieving the middle-income level is diversity in production, the goal of being able to move to a higher level of income is to focus on specific areas and specialize in the manufacturing and service sectors. This is the rule of scale economy. It would be wise to direct national energies (savings, investments, human capital and all other inputs) to some special products and sectors in order to be able to move from middle-incomes towards high income levels. Especially 
after the East Asian crisis, South Korea focused on a couple of selected sectors: the electronics and automotive industries. As giant corporations of S. Korea went bankruptcy the remaining ones conducted serious restructuring processes. The East Asian Crisis was seen as an opportunity for the transition to high-efficiency sectors.

The second important model which emerges from the process of national economic transformation into high-income level in successful countries is related to total factor productivity. Undoubtedly, the key to total factor productivity is education policies. The third point in the transition from the middle incomes to the high income levels is expressed as decentralization principle (Kharas and Kohli, 2011). More specifically, power, authority and responsibility are to be distributed in a coordinated manner in macro economic management. Local governments are both weak in terms of capacity and pressures against private interest groups. For that, political power and responsibility should be distributed proportionally.

Another major recommendation for middle-income trap and development is to change economic philosophy or mentality. In particular, policies on social programs need to be formulated independently. With a simple statement, a demandoriented production structure should be targeted for transition. In this regard, we can give populist practices in Turkey such as the elimination of student fees at universities and distribution of free milk to elementary school students.

The main objective of the economic development strategy should be quality and innovation-based production that can address the world markets. On the other hand, the states should deal with the distribution - redistribution policies, as the government's main task, in separate circles in order to be able to meet the need for social justice. Although education is regarded as a public property, higher education is more like a private property since its rate of return is quite high for the owner. The compulsory education in South Korea is 9 years $(6+3)$, but the fact that Turkey's introduction to 12 yearscompulsory education is a controversial subject.

In sum, a high quality education system, especially the higher education system, should be restructured in a rational incentive-based system. Rewards and punishment have to be inserted in the institutional codes. In order to get rid of middle income trap, Turkish education system must be focused on productivity rather than equality.

In order to escape from the middle income trap and to achieve high income status, Turkish authorities should design a comprehensive reform project prioritizing total factor productivity at all levels and stakeholders of the system. Without radical reforms it is impossible to position Turkey amongst the top 10 economies of the world by 2023 or even by 2050 .

As it is frequently expressed by scholars and experts, Turkey needs to focus on the technologically advanced products. The kilogram value of Turkey's exports is around $\$ 1.5$, while in advanced countries such as Germany and Japan this figure is around $\$ 4.5$. One of the preconditions of high technology production and export is quality-oriented universities and other research institutions.

There are certain requirements for producing high technology products. For example, Drori (2010) discussed about these requirements. There are three essential factors on the matter. First, there is a social geography of innovation: Silicon Valleylike technology clusters have been emerged around the world, and the vast majority of them are concentrated in a few regions or countries. It is becoming increasingly difficult to enter into the league of world tech giants. As of 2008, almost half of the 4,000 innovation centers around the world are in the United States. The vast majority of worldwide patents are concentrated in five centers: the United States, Japan, South Korea, PRC and European Patent offices, which signed about $77 \%$ of the 727,000 patents registered in 2006 . The second factor mentioned by Drori (2010) is the innovation infrastructure. From the financial aspect of $R \& D$ activities to legal protection infrastructure, many factors have been examined in this group. The third important factor mentioned by Drori (2010) is the socio-cultural dimension of innovation or ecosystem. Taking social values and norms into account, the overall picture of entrepreneurship, risk taking and business administration and similar activities should be examined.

To support Drori's (2010) major parameters for innovation and development there is a trend in the structure of higher education globally. Quality of universities now is associated with their rank in the world league. Besides, higher education institutions tend to cluster around "university hubs". As the center of gravity shifts towards the Asia Pacific region, Asian universities are also on the rise globally. Of the top 200 universities in the world, there are five from the PRC, three from the South Korea, and two from Singapore and Japan.

Moreover, the concepts of innovation and knowledge economy become more meaningful together with sociology and geography. Innovation has a geographical dimension along with sociological dynamics. Techno-parks, global cities, "smart cities", "competitiveness of cities" and "viable cities index", all these novel concepts are related to innovation ecosystem. In order to be able to attract talent it is necessary to provide for a livable environment to scholars and research personnel (Gill and Kharas, 2015). For example, Mercer's Quality of Living Index has been evaluating and ranking 230 cities of the world over 39 parameters including politics, economy, environment, safety, health, transportation for almost ten years. According to this ranking, Vienna is at the top of the list as the most livable city.

Although the deficiencies in Turkey's education system and in particular the higher education system are partly referred to as inadequate resources, the most important problem is the lack of an all-inclusive system. In Turkey, both the number of universities and the number of enrolled students have experienced a huge increase in the last decade; the number of universities, which was 73 in 2004, reached 180 by 2016 . While the number of students enrolled in universities and colleges 
was approximately 2 million in 2004, this figure reached 6 million by 2016. The schooling rate, which was $31 \%$ in 2004 , approached $80 \%$ by 2016 ; It is worth noting that the OECD average was $70.2 \%$ in 2014 (Tekneci, 2016).

One of the most important indicators of educational quality is government expenditure per student figures. It is striking that Turkey is one of the lowest-ranking countries among OECD countries in terms of education expenditure per student. According to the OECD data for 2015, when the expenditure per student is examined, Turkey with about 2,500 euros is in the last places of the list (OECD, 2016). It is observed that the share of education budget in Turkey has increased in recent years. The ratio of the amount of public resources spent for the national education system (including public universities) to GDP has reached 4\%. However, the OECD average in this area is around 5-6\%. According to 2011 figures, public spending for higher education institutions is $1.63 \%$ of OECD average GDP, while this figure is $1.32 \%$ in Turkey (Tekneci, 2016).

In addition, approximately $80 \%$ of the tuition allocated to the education system in Turkey is allocated to personnel expenditures. The funds received by the top ten universities of Turkey from the national budget are around 2.4 billion dollars. To make a comparison, let us recall that the US public budget allocation for Harvard University in 2013 was $\$ 4.2$ billion. In addition, as announced by Harvard University, the amount donated to college by graduates and other beneficiaries at the end of the 2013 budget year was $\$ 32.7$ billion (Harvard Magazine, September 24, 2013).

Universities in Turkey are not still accustomed to generate financial resources. By Abbas Guclu's statement, "Universities should produce part of their own resources. The world's advanced universities provide one-third of the budgets from the state, one-third from the students, and one third from their own fund raising activities. In Turkey, almost $95 \%$ of the resources are coming from the public funds for state universities (Milliyet, July 3, 2015). While the ratio of administrative to academic staff in the prominent world universities does not reach $5 \%$, in Turkey the number of administrative staff is almost the same as the academic staff in Turkish universities (Milliyet 3 July 2015; Özoğlu et al., 2016).

Another problem area regarding the input structure of the Turkish higher education system is the relative weakness of internationalization. While there are approximately 150 thousand academic personnel in Turkey, the number of foreign academics is 1703 , representing about $2 \%$ of total (Şeremet, 2015). Moreover, the vast majority of foreign faculty members have been clustered at several major universities, such as Bilkent and Koç Universities. In a comparative study of the global higher education systems by the British Council (2016), the major deficiencies of Turkey are highlighted in internationalization, institutionalization areas and more importantly in quality assurance and international recognition.

One of the most important inputs of the higher education system is related to the academic staff. According to a study conducted by TUBITAK (2015) using 2004-2014 data, the number of publications addressed in Turkey was 228,856 and $1,517,691$ cited works. The first three universities ranks according to impacts of publications were Boğaziçi University, Bilkent University and iTÜ. Another data suggests that publications in only 17 fields out of the 250 Turkish universities were ranked above the world average in terms of impact factor.

In South Korea, the top 10 universities have been selected by the government and bureaucratic authorities and these universities are planned to enter into world class universities by providing serious incentives. The Brain Korea 21 project and World-Class-University-WCU projects were influential (Byun et al., 2013). Another project, "Work in South Korea Project" aimed to attract talented students and researchers. The South Korean Advanced Institute of Science and Technology (KAIST) was established to attract Korean scientists from developed countries to the homeland (Michalski et al., 2012). In the period between 2003 and 2011, 10 universities of the South Korea entered into the top 500 universities in the world rankings (Michalski et al., 2012). In China it is observed that the 11th economic plan allocated a special section for university education and university system. With the 11th Development Plan, the PRC government aimed to have a sustainable development strategy for all educational institutions, especially universities. The PRC issued the 13th Development Plan (2016-2020) and the second section is "Innovation-Driven Economic Development." In the most recent plan, the goal is developing worldwide universities, enabling PRC to become the world leader in certain disciplines. The PRC government has identified a specific number of universities in the elite university category.

\section{CONCLUSION}

Taking into consideration Turkey's financial limittaions, resources allocated to universities and R\&D activities should be used wisely. Firstly, higher proportions of budget should be allocated to the education and R\&D activities. Secondly, the existing source should be used in the most efficient way. Making the Turkish economy more innovative and more competitive is only possible by high quality knowledge production system.

The necessity of producing high-tech products in Turkey has been understood and a number of incentives and measures have been included especially in the 9th and 10th Development Plans to achieve this aim. Furthermore, in the National Science, Technology and Innovation Strategy (2011-2016) prepared by TUBITAK, the areas with high innovation capacity including of automotive, machine manufacturing, information and communication technologies, defense, space, health, energy, water and food sectors are invested and it is accomplished in the form of university - industry cooperation.

The most critical step Turkey needs to take is construction of a commonly shared strategic vision. All stakeholders should agree on this vision. All public institutions predominantly the YÖK must be redesigned in a holistic policy. The entrepreneurship and innovation index produced by TUBITAK for Turkey's universities is an important step. To move into 
high income league Turkey must focus on the concept of elit universities. In order for Turkey's universities to reach global standards, at least some of them must operate in autonomous status.

It is necessary for Turkish decision-makers to focus on productivity and efficiency oriented economic reforms. This is a reform program that must focus on educational reform in general and engineering and science programs that will provide, in particular, human capital for Turkey's elite universities and a few selected sectors for high tech export advantage. It is necessary for Turkey to construct a development model that is appropriate for its culture, history, demographic structure and all other socio-political realities.

For the basic principles of this model, it is necessary to pay attention to some of the problems that are present in the current development levels of these countries as well as the important features such as efficiency, innovation and research development from South Korea, Singapore, PRC and Japan models. Also, such issues as demographic sustainability, consumption-waste-saving relationships and social capital sustainability should be taken into account while planning and implementing reforms of higher education development. For example, South Korean experience of getting rid of the middle-income trap can be used as a model in this regard, but it also has alarming points in some aspects: South Korea is in the first place according to the World Health Organization for suicide cases. According to 2013 data, the number of deaths due to suicide per 100,000 population is 28.5 in South Korea, and 21.4 in Japan, while this figure is around 4 for Turkey (WHO, 2014). Likewise, in terms of population growth rate, South Korea, PRC and Japan are expected to face serious problems like all other developed countries. In short, in the course of planning and implementation of Turkey's economic growth and development policies, attention should be paid to other important social and political parameters such as fertility, suicide, divorce, social capital, in addition to economic parameters such as productivity.

\section{REFERENCES}

Agenor, P.R., Canuto, O., Jelenic, M. (2012), "Avoiding Middle-Income Growth Traps," World Bank - Economic Premise, No: 98.

Aiyar, S., Duval, R. Puy, D., Wu, Y. \& Zhang, L. (2013), “Growth Slowdowns and the Middle-Income Trap," International Monetary Fund Working Paper, March 2013.

Byun, K. Jon, J.E., Dongbin, K., (2013), “Quest for Building World-class Universities in South Korea: Outcomes and Consequences”, Higher Education, 65, 645-659

Economist (2011), “Beware The Middle-İncome Trap: China's Roaring Growth Cannot Last Indefinitely", June 2011

Eurostat (2014), “Annual expenditure on public and private educational institutions per pupil/student," Available at http://ec.europa.eu/eurostat/tgm/

Felipe, J. Abdon, A., \& Kumar, U. (2012), "Tracking the Middle Income Trap: What Is It, Who Is In It, and Why?" Levy Economics Institute Working Paper, No: 715.

Gill, I. \& Kharas, H. (2007), “An East Asia Renaissance: Ideas For Economic Growth”, Washington DC: World Bank.

Gill, I. S., \& Kharas, H. (2015). The middle-income trap turns ten.

Interbrand (2014), "Best Global Brands," Available at: http://www.bestglobalbrands.com/2014/ranking/

Jon, J. \& Chung H. (2014), STEM Report: Country comparisons: Republic of Korea,

http://www.acola.org.au/PDF/SAF02Consultants/Consultant\%20Report\%20-\%20Korea.pdf

Kharas, H. \& Harinder, P. (2011), "What Is the Middle Income Trap, Why do Countries Fall into It, and How Can It Be Avoided?", Global Journal of Emerging Market Economies, 3(3), 281-289.

Kohli, H.A. \& Mukherjee, N. (2011), "Potential Costs to Asia of the Middle Income Trap", Global Journal of Emerging Market Economies, 3(3), 291-311.

Kohli H.A., Szyf, Y.A., \& Arnold, D. (2012), "Construction and Analysis of a Global GDP Growth Model for 185 Countries through 2050 ”, Global Journal of Emerging Market Economies, 4(2), 91-153.

Li, Y.A., Whalley, J., Zhang, S. \& Zhao, X. (2011), "The Higher Educational Transformation of China and Its Global Implications", The World Economy, 34(4), 516-545

Michalski, B., Kołodziej, G. \& Piasecka, A. (2012) Organization and functioning of South Korean Higher Education System”., Adam Marszałek, Toruń (ed.), Is the 21st Century the Age of Asia? Deliberations on Culture and Education. Available at: http://www.researchgate.net/publication/232815596

Moon, M. \& Kim, K. (2001), “A case of Korean Higher Education Reform: The Brain Korea 21 Project”, Asia Pacific Education Review, 2(2), 96-105.

Mowery, D. C. \& Sampat, B.N. (2013), “Universities in National Innovation Systems,”. J. Fagerberg, D. C. Mowery \& R. R. Nelson (Ed.), The Oxford Handbook of Innovation, Oxford: Oxford University Press, 1-38.

OECD (2012), "International Comparisons," Main Science and Technology Indicators, Available at:http://www.oecd-ilibrary.org/scienceand-technology/main-science-and-technology-indicators/volume-2011/issue-2_msti-v2011-2-en-fr 
Sharma, Y. (2014), What Do You Do with Millions of Extra Graduates?, BBC-News (1 Temmuz 2014): Available at: http://www.bbc.com/news/business-28062071

TÜBiTAK (2017), Girişimci ve Yenilikçi Üniversite Endeksi-2016, Available at: http://www.tubitak.gov.tr/tr/kurumsal/politikalar/icerikgirisimci-ve-yenilikci-universite-endeksi

UNDP (2014), Human Development Report-2014.

World Health Organization (2014), "Preventing suicide: A global imperative”, Available at: http://www.who.int/mental_health/suicideprevention/world_report_2014/en/

Wilson, W.T. (2014), "Beating the Middle-Income Trap in Southeast Asia," Special Report No. 156, Heritage Foundation, 27 August 2014.

World Bank (2014), World Development Indicators 2014. 